\title{
SOME MYCOTOXINS CONTAMINATION IN ANIMAL FEED AND FEEDSTUFF INGREDIENTS IN DUHOK PROVINCE
}

\author{
EMAD T.SADEEQ \\ Dept. Animal Production, College of Agricultural Engineering Sciences, University of Duhok, \\ Kurdistan Region-Iraq
}

(Received: August 30, 220; Accepted for Publication: September 30, 2020)

\begin{abstract}
Fungi produce different types of mycotoxin under improper storage conditions and during crops growing period which cause chronic or acute animal toxicities. Aflatoxin B1, Ochratoxin A and T-2 toxin are mycotoxins that pose a threat to human and animal health. This study was carried out to determine AFB1, OTA and T-2 levels in animal feed and feedstuffs materials used in animal feed factories and livestock enterprises throughout Duhok province. The samples that used for analysis (35 mixed feeds and 54 feedstuffs materials) collected from different feed factories and enterprises. Mycotoxins concentrations were quantified by using immunoassay (ELISA). Results showed that positive samples for AFB1 found in $7(7.87 \%)$, OTA were $21(23.60 \%)$ and T-2 were $8(8.99 \%)$ from 89 samples analysed, whereas negative samples found for AFB1 were 82 (92.13\%), OTA were 68 (76.40\%) and T-2 were 81 (91.01).
\end{abstract}

KEYWORDS: Animal mixed feed: Animal feedstuffs: mycotoxin: Aflatoxin B1: Ochratoxin A: T-2 toxin.

\section{INTRODUCTION}

$\mathbf{M}$ ycotoxins are secondary metabolites with low molecular weight produced by some fungi strains such as Fusarinm, Pencillium and, Aspergillus, which develop during crops production in field and invade food under improper storage conditions with high amount of temperature and humidity (Iheshiulor et al., 2011). Over the world, there are more than 100 fungi species that may invade plants and produce mycotoxins (Sultana and Hanif, 2009). Crops infections develop during various production stage by mycotoxin and mold production at end stage of growth in the field, during crops harvesting and storage (Martins et al., 2007). Mycotoxins implicate regularly in their toxic syndromes in both humans and animals (charoenpornsook and Kavisarasai, 2006 and Wayne, 2007). By the intensity of mycotoxins synergetic effect and toxic properties, they are considered as health risk to the consumers with contaminated feed and food (Yiannikoiuis and jonany, 2002; Omede, 2008).

Mycotoxins have been found in all parts of the world and detected in different commodities of food and considered as the most dangerous contaminants crops production and animal feed (Okoli et al., 2006a,b; Okoli et al., 2007 a,b). Researches showed that there is no parts of the world escape from mycotoxin effects and according to Lawlor and Lynch, (2005) and Okoli et al., (2006b), they estimated that mycotoxins are effect more than $25 \%$ of the crops production around the world per year. They are produced only in the aerobic environments (Ratcliff, 2002). Their negative effects have been well recognized on animal production and health when animals farmed intensively such as cattle, swine and poultry enterprises as a consequence of the consumption of high amount diet with of oilseeds and cereals (charoenpornsook and Kavisarasai, 2006). Inhibition of protein synthesis occur by many types of mycotoxins such as Aflatoxin B1 (AFB1), Ochratoxin A (OTA) and T-2 toxin (T2) (charoenpornsook and Kavisarasai, 2006). This inhibition may be the secondary mechanism involve in their immunotoxic activity. They may effect selectively on many target organs, damage membranes or intervenes with macromolecular functions and synthesis. (Sharma, 1993).

Mycotoxins formation in nature was considered a global problem, however, in certain geographical areas of the world, some mycotoxins are produced more readily than other (Ratcliff, 2002; Lawlor and Lynch, 2005). The Mycotoxins problem does not end in animal feed or detraction its performance may become accumulated in animal products (e.g; meat, egg 
and milk) by which transmit to human food and pose a threat to human health (Akande et al., 2006). Therefore, the current experiment was designed to study the contamination of some mycotoxins in animal feed and feedstuff ingredients in Duhok province.

\section{MATERIALS AND METHODS 2.1. FEED AND FEEDSTUFFS SAMPLES}

Over this study, 89 samples (35 mixed feeds and 54 feedstuffs samples) were collected from different livestock enterprises and animal feed factories during the summer season in July and August 2019 in Duhok province. Samples were gathered according to a method determined by Ergun et al., (2007). Feed samples consisted of sheep $(n=17)$, cattle $(n=8)$ and poultry $(n=10)$ rations, while feedstuffs samples include corn $(n=14)$, wheat $(n=7)$, barley $(n=11)$, sunflower seed $(n=3)$, chick pea $(n=2)$, sorghum $(n=3)$, soybean meal $(n=7)$ and wheat bran $(n=7)$. The samples taken from storage at the enterprises were kept at $+4^{\circ} \mathrm{C}$ in the refrigerator and analyzed within one week.

\subsection{BIOCHEMICAL ANALYSES}

Levels of mycotoxins AFB1, OTA and T-2 in feed samples were determined by ELISA device (BioTek ELx800 Absorbance Microplate Reader, USA) using the commercial kit (BIO SCIENTIFIC, Art No: 1055-04 for AFB1, 103602 OTA and 1037-01 for T-2) via the competitive inhibition enzyme immunoassay method based on the manufacturer's procedure. Limit of detection for AFB1, OTA and T-2 in feed were $0.4 \mathrm{ppb}, 0.15 \mathrm{ppb}$ and $10 \mathrm{ppb}$ respectively as the described method according to Elisa kit procedure (BIO scientific crop, 2016). Weighed out $5 \mathrm{~g}$ of the each ground and $25 \mathrm{~mL}$ of $70 \%$ Methanol were added and vortex vigorously for 3 minutes, Centrifuge the samples for 10 minutes at $4,000 \mathrm{xg}$ at room temperature $\left(21{ }^{\circ} \mathrm{C}\right)$. About $50 \mu \mathrm{l}$ taken from each preprocessed sample was added to the wells. They were incubated for 30 minutes at room temperature and in a dark place after adding by adding $100 \mu \mathrm{l}$ of conjugate enzyme. Then $100 \mu \mathrm{l}$ TBM substrate was added and incubated for 15 minutes and by adding $100 \mu \mathrm{l}$ of Stop Buffer to stop the enzyme reaction then the plates were Read on a plate reader with $450 \mathrm{~nm}$ wavelength (Gumus et al., 2018).

\subsection{STATISTICAL ANALYSIS}

SPSS 20.00 statistical software program used to estimate mean, standard deviation, minimum and maximum values of mycotoxin data (SPSS Chicago, 2011).

\section{RESULT AND DISCUSSION}

The mixed feed and feedstuffs ingredient samples with mean $\pm \mathrm{Sx}$, minimum and maximum values for mycotoxins; AFB1, OTA and T-2 are given in Table 1.

Table (1): Levels of mean, minimum and maximum of Aflatoxin B1, Ochratoxin A and T-2 toxin in mixed feed and feedstuffs ingredients (ppb).

\begin{tabular}{|c|c|c|c|c|c|c|c|c|c|c|}
\hline \multirow[t]{2}{*}{ Feeds } & \multirow[t]{2}{*}{$\mathbf{n}$} & \multicolumn{3}{|c|}{ Aflatoxin B1 } & \multicolumn{3}{|c|}{ Ochratoxin A } & \multicolumn{3}{|c|}{ T-2 toxin } \\
\hline & & $X \pm S x$ & Min & $\operatorname{Max}$ & $X \pm S x$ & Min & Max & $X \pm S x$ & Min & Max \\
\hline \multicolumn{11}{|l|}{ Mixed Feeds } \\
\hline Sheep Feed & 17 & $0.080 \pm 0.029$ & 0.00 & 0.46 & $0.092 \pm 0.012$ & 0.00 & 0.18 & $1.953 \pm 0.651$ & 0.0 & 11.4 \\
\hline Cattle Feed & 8 & $0.085 \pm 0.060$ & 0.00 & 0.49 & $0.055 \pm 0.019$ & 0.00 & 0.17 & $3.69 \pm 1.12$ & 1.9 & 11.0 \\
\hline Poultry Feed & 10 & $0.113 \pm 0.044$ & 0.00 & 0.49 & $0.111 \pm 0.025$ & 0.02 & 0.2 & $2.84 \pm 1.59$ & 0.0 & 12.4 \\
\hline \multicolumn{11}{|l|}{ Feedstuffs } \\
\hline Corn & 14 & $0.134 \pm 0.042$ & 0.00 & 0.48 & $0.073 \pm 0.018$ & 0.00 & 0.18 & $2.66 \pm 1.05$ & 0.0 & 15.2 \\
\hline Wheat & 7 & $0.056 \pm 0.026$ & 0.00 & 0.16 & $0.032 \pm 0.011$ & 0.00 & 0.08 & $3.26 \pm 1.25$ & 0.0 & 10.45 \\
\hline Barley & 11 & $0.093 \pm 0.040$ & 0.00 & 0.42 & $0.116 \pm 0.021$ & 0.00 & 0.19 & $2.30 \pm 0.94$ & 0.0 & 11.00 \\
\hline Sun flower seed & 3 & $0.350 \pm 0.153$ & 0.05 & 0.55 & $0.046 \pm 0.018$ & 0.02 & 0.08 & $4.60 \pm 3.60$ & 0.0 & 11.70 \\
\hline Chick pea & 2 & $0.270 \pm 0.220$ & 0.05 & 0.49 & $0.114 \pm 0.094$ & 0.02 & 0.208 & $1.04 \pm 1.04$ & 0.0 & 2.08 \\
\hline Sorghum & 3 & $0.087 \pm 0.059$ & 0.00 & 0.20 & $0.068 \pm 0.012$ & 0.04 & 0.084 & $1.13 \pm 0.61$ & 0.0 & 2.10 \\
\hline Soybean meal & 7 & $0.019 \pm 0.008$ & 0.00 & 0.04 & $0.086 \pm 0.023$ & 0.02 & 0.168 & $0.80 \pm 0.52$ & 0.0 & 2.90 \\
\hline Wheat bran & 7 & $0.060 \pm 0.016$ & 0.00 & 0.12 & $0.053 \pm 0.023$ & 0.00 & 0.18 & $1.29 \pm 0.49$ & 0.0 & 2.70 \\
\hline
\end{tabular}

$\mathrm{X} \pm \mathrm{Sx}$ : refer to mean \pm Standard error, Min: minimum, Max: maximum. 


\subsection{AFLATOXIN B1}

In the present study, AFB1 contamination was found to be $5.71 \%$ in animal mixed feed and $9.26 \%$ in feed ingredients. Seventeen samples of sheep feed out of total 89 different feed and feed ingredients are analysed an overall all samples were found within no AFB1 contamination (Table 2). Cattle feed samples were observed $12.5 \%$ and for poultry feed were found $10.0 \%$ within limited detection range.

For feed ingredients, the AFB1 detected contamination rate were $14.29 \%, 0.0 \%, 9.01 \%$, $66.67 \%, 50.0 \%, 0.0 \%, 0.0 \%$ and $0.0 \%$ for each corn, wheat, barley, sunflower seed, chick pea, sorghum, soybean meal and wheat bran respectively. Similarly, Hashemi (2016), studied 359 different feed and feedstuffs and found contaminated samples with AFB1 at different percentage ratios including; cattle feed $12.50 \%$, Wheat bran $10 \%$, corn $35.71 \%$, barley $0.0 \%$, cotton seed meal $0.0 \%$, soybean meal $20 \%$, wheat flour $0.0 \%$ and meat powder $0.0 \%$.

Patterson and Roberts, (1980), reported during a survey study that conducted over a period of 13 years on the detection AFB1 taken 740 samples of animal mixed feeds, including dairy feeds, $27 \%$ of the feed samples were contaminated with toxin, at the higher level of more than $30 \mu \mathrm{g} / \mathrm{kg}$. Whereas Rodrigues et al., (2011) studied on 324 grain, feed and feedstuff ingredients in the Middle East and Africa and found the high percentage of AFB1 detection among the analysed samples, including maize, wheat, poultry mixed feed, pig feed, grass silage, wheat bran, soybean meal and other feedstuffs, the percentage of positive samples were; $93 \%$, $82 \%, 100 \%, 100 \%, 99 \%, 19 \%, 24 \%$ and $38 \%$ respectively. In accordance with the result demonstrated in a study conducted on maize, the AFB1 content was found in a percent of $77 \%$ (Sauza et al., 2013). Martins et al., (2007), mentioned that AFB1 monitoring by the feed industry, beside awareness to some of breeders is quite recommended and beneficial, since AFB1 cause animal's health disorders and the contaminated milk with this mycotoxin can be a serious hazard for human health.

Table 2: Aflatoxin B1, ochratoxin A and T-2 toxin levels in mixed feeds and feedstuffs ingredients.

\begin{tabular}{|c|c|c|c|c|c|c|c|c|c|c|c|c|c|}
\hline \multirow{3}{*}{ Feeds } & \multirow{3}{*}{$\mathrm{n}$} & \multicolumn{4}{|c|}{ Aflatoxin B1 } & \multicolumn{4}{|c|}{ Ochratoxin A } & \multicolumn{4}{|c|}{ T-2 toxin } \\
\hline & & \multicolumn{2}{|c|}{ Undetected } & \multicolumn{2}{|c|}{ Detected } & \multicolumn{2}{|c|}{ Undetected } & \multicolumn{2}{|c|}{ Detected } & \multicolumn{2}{|c|}{ Undetected } & \multicolumn{2}{|c|}{ Detected } \\
\hline & & $\mathrm{n}$ & $\%$ & $\mathrm{n}$ & $\%$ & $\mathrm{n}$ & $\%$ & $\mathrm{n}$ & $\%$ & $\mathrm{n}$ & $\%$ & $\mathrm{n}$ & $\%$ \\
\hline \multicolumn{14}{|l|}{ Mixed Feeds } \\
\hline Sheep Feed & 17 & 17 & 100 & 0 & 0.0 & 14 & 82.35 & 3 & 17.65 & 16 & 94.12 & 1 & 5.88 \\
\hline Cattle Feed & 8 & 7 & 87.5 & 1 & 12.5 & 7 & 87.5 & 1 & 12.5 & 7 & 87.5 & 1 & 12.5 \\
\hline Poultry Feed & 10 & 9 & 90.0 & 1 & 10.0 & 6 & 60.0 & 4 & 40.0 & 8 & 80.0 & 2 & 20.0 \\
\hline \multicolumn{14}{|l|}{ Feedstuffs } \\
\hline Corn & 14 & 12 & 85.71 & 2 & 14.29 & 11 & 78.57 & 3 & 21.43 & 13 & 92.86 & 1 & 7.14 \\
\hline Wheat & 7 & 7 & 100.0 & 0 & 0.0 & 7 & 100.0 & 0 & 0.0 & 6 & 85.71 & 1 & 14.29 \\
\hline Barley & 11 & 10 & 90.91 & 1 & 9.01 & 5 & 45.45 & 6 & 54.55 & 10 & 90.91 & 1 & 9.01 \\
\hline Sun flower seed & 3 & 2 & 33.33 & 1 & 66.67 & 3 & 100.0 & 0 & 0.0 & 2 & 66.67 & 1 & 33.33 \\
\hline Chick pea & 2 & 1 & 50.0 & 1 & 50.0 & 1 & 50.0 & 1 & 50.0 & 2 & 100.0 & 0 & 0.0 \\
\hline Sorghum & 3 & 3 & 100.0 & 0 & 0.0 & 3 & 100.0 & 0 & 0.0 & 3 & 100.0 & 0 & 0.0 \\
\hline Soybean meal & 7 & 7 & 100.0 & 0 & 0.0 & 5 & 71.43 & 2 & 28.57 & 7 & 100.0 & 0 & 0.0 \\
\hline Wheat bran & 7 & 7 & 100.0 & 0 & 0.0 & 6 & 85.71 & 1 & 14.29 & 7 & 100.0 & 0 & 0.0 \\
\hline Mixed Feeds & 35 & 33 & 94.29 & 2 & 5.71 & 27 & 77.14 & 8 & 22.86 & 31 & 88.57 & 4 & 11.43 \\
\hline Feedstuffs & 54 & 49 & 90.74 & 5 & 9.26 & 41 & 75.93 & 13 & 24.07 & 50 & 92.59 & 4 & 7.41 \\
\hline Total & 89 & 82 & 92.13 & 7 & 7.87 & 68 & 76.40 & 21 & 23.60 & 81 & 91.01 & 8 & 8.99 \\
\hline
\end{tabular}

\subsection{OCHRATOXIN A}

The percentage and numbers of detected and undetected OTA in mixed feed and feedstuff ingredients are shown in Table 1 . The results showed that OTA ratio was $24.07 \%$ in feedstuffs ingredients and $22.86 \%$ in mixed feeds, while these value are lower than limited safety range for OTA in feeds, it may cause animal health problems and loss its production when consume feeds for a long period time 
(Moura et al., 2004). The results of study conducted in Turkey showed that the ratio of OTA was $47.83 \%$ in feedstuffs materials, while it was $66.67 \%$ in mixed feeds (Yıldız, 2009). In another study, the ratio of OTA found to be $74.58 \%$ in mixed feeds and $66.67 \%$ in feedstuffs materials (Gumus et al., 2018). Araguás et al., (2005), analysed 72 different cereal crops samples, found $9 \%$ of the samples were contaminated with OTA and only 2 samples have the value above the allowed limit range. Similarly Vega et al., (2009) studied 91 crop grain and demonstrate that only 1 sample of OTA had toxin above the allowed value. In the other study it was found only 2 samples from 56 had OTA value more than limit value (Altintas et al.2011).

Current study showed the samples taken from sheep, poultry and cattle feed have OTA $17.65 \%, 12.5 \%$ and $40.0 \%$ respectively above the limited of detection (Table 1). Yıldiz, (2009), concluded in a survey study that $60.00 \%$ of cattle feed samples contaminated with OTA above limited detection value. While Rosa et al., (2008) showed that 25\% for finished cow's feed had positive OTA, $31 \%$ corn samples and $22 \%$ for barley samples. Sonal \& Oruc, (2000) was reported that $100 \%$ of the poultry feed samples taken from poultry enterprises around Bursa province had OTA value above the detection limit, while in our study there was only $40.0 \%$ of poultry feed contaminated with OTA. However, it is well known that the likelihood a value of only one mycotoxin being found with very low amount in the mixed feed and feedstuff, but it is known that many types of mycotoxins produced by the same species of fungi and simply infest animal feed (Hussein \& Brasel, 2001). In our results, we found that $0.0 \%, 28.57 \%$ and $14.29 \%$ of samples contaminated with OTA of feedstuffs ingredient for sunflower seed, soybean meal and wheat bran respectively, while Gumus et al., (2018) reported that OTA was higher than allowed limited value in sunflower meal $(80.00 \%)$; soybean meal $(66.66 \%)$ and wheat bran $(60.00 \%)$. The studied results by Kaya et al., (1990) are highly quite when compared to our results, which may be due to the some factors such as regional differences, climate conditions, and humidity of the atmosphere.

\subsection{T-2 TOXIN}

The T-2 numbers performed tests on mixed feed and feedstuffs samples, number of the respective positive and negative ratios were summarized in Table 1. The frequency of positive samples for T-2 was $11.43 \%$ and $7.41 \%$ in mixed feed and feedstuff ingredients, respectively. These results were lower than that analysed by Souza et al., (2013), and demonstrate that complete feed and feedstuffs ingredients had $98.0 \%$ and $100 \%$ T-2 contamination, respectively. In our study, the incidence of T-2 were $5.88 \%$ for sheep feed, $12.5 \%$ for cattle feed and $20.0 \%$ for poultry feed, while for feedstuff ingredients such as corn, wheat, barley, sunflower seeds, chick pea, sorghum, soybean meal and wheat bran were; $7.14 \%, 14.29 \%, 9.01 \%, 33.33 \%, 0.0 \%, 0.0 \%$, $0.0 \%$ and $0.0 \%$, respectively. However, Rodrigues et al., (2011), reported that corn contaminated with T-2 at ratio of $94.8 \%$, wheat 94.9\%, and barley 95.3\%. While Marijani, et al., (2019) showed feedstuff samples had t-2 such as corn, soybean meal and cotton seed at the rate of $3.4 \%, 16.7 \%$ and $4.9 \%$, respectively. Kocasari et al., (2013), by using ELISA method analysed 180 cattle and lamb feeds and reported that T-2 toxin were found in samples 85 (47.2\%).

A wide range of T-2 toxicity can cause: loss of body weight, diarrhoea, pests in liver and digestive system disorders ( $\mathrm{Li}$ et al., 2011). Especially in poultry it reduce egg yield production, decrease hatching egg and defeathering are some symptoms of chronic exposure to high dose of T-2 (Diaz et al., 1994; Wyatt et al., 1975). In addition, T-2 causes oral cavity ulcers which can be also the factor that depress animal feed intake (Wyatt et al., 1973).

\section{CONCLUSION}

This study revealed that AFB1, OTA and T-2 may be found in majority of the complete feed and feedstuffs ingredient in animal farms of the Duhok province. Mycotoxins concentration of AFB1 OTA and T-2 in proportions of mixed feed $(5.71 \%, 22.86 \%$ and $11.43 \%)$ and feedstuff ingredients $(9.24 \% 24.07 \%$ and $7.41 \%)$ samples had higher values than limited of detection. Therefore, there should be regulate a program for monitoring the mycotoxins in animal feed and feedstuffs commodities and destined for animal consumption feed that produced locally or imported to prevent animal from mycotoxins toxicity and also their formation and transportation to animal products. 


\section{REFERENCES}

Akande, K.E., Abubakar, M.M., Adegbola, T.A. and Bogoro, S.E. (2006). Nutritional and health implicationof mycotoxin in animal feeds. A review. Pakistan Journal of Nutrition; 5, 398403.

Altintas, L., Ekici, H., Yarsan, E., Cakır, S., Evrensel, M.F. and Tokgoz, B.S. (2011). Investigation of the total aflatoxin, aflatoxin B1 and ocratoxin A residues in the ruminant and poultry feeds obtained from Ankara, Konya and Bolu. Journal of Etlik Veterinary Microbiology; 2, 61-67.

Araguás, C., González-Peñas, E. and Cerain, A.L. (2005). Study on ochratoxin A in cereal derived products from Spain. Food Chemistry; 3, 459-464.

Charoenpornsook, K. and Kavisarasai, P. (2006). Mycotoxin in animal feedstuff of Thailand. KMILT Science Technology Journal; 6, 2528.

Diaz, G.J., Squires, E.J., Julian, R.J. and Boermans, H.J. (1994). Individual and combined effects of T-2 toxin and DAS in laying hens. Brazil Poultry Science; 35, 393-405.

Ergun, A., Tuncer, S.D., Colpan, I., Yalcın, S., Yildiz, G. and Kucukersan, M.K. (2007). Feeds, feed hygiene and technology. 3rd edition Ankara: Positive Press; 309-312.

Ergun, A., Tuncer, S.D., Colpan, I., Yalcin, S., Yıldiz, G. and Kucukersan, M.K. (2007). Feeds, feed hygiene and technology. 3rd edition Ankara: Positive Press; 309-312.

Gumus, R., Ercan, N. and Imik, H. (2018). Determination of ochratoxin A levels in mixed feed and feed stuff used in some laying hens and ruminant enterprises of Sivas city. Brazilian Journal of Poultry Science; 1, 85-90.

Hashemi, M. (2016). Aflatoxin B1 levels in feedstuffs from dairy cow farms in south of Iran, Food and Agricultural Immunology; 2, 251-258.

Hussein, H.S. and Brasel, J.M. (2001). Toxicity, metabolism, and impact of mycotoxins on humans and animals. Toxicology; 2, 101-134.

Iheshiulor, O.O., Esonu, B.O., Chuwuka, O.K., Omede, A.A., Okoli, I.C. and Ogbuewu, I.P. (2011). Effect of mycotoxins in animal nutrition: Areview. Asian Journal of animal Science; 1, 19-33.

Kaya, S., Yavuz, H. and Akar, F. (1990). Mycotoxin residues in some oily seed meals. Veterinary Journal of Ankara University; 1,173-180.

Kocasari, F.S., Mor, F., Oguz, M.N. and Oguz, F.K. (2013). Occurrence of mycotoxins in feed samples in Burdur Province, Turkey. Environment Monit Assessment; 6, 4943-9.
Lawlor, P.G. and Lynch, P.B. (2005). Mycotoxin management. African Farming Food Process; 46, 12-13.

Li, Y., Wang, Z., Beier, R.C., De Shen, J., De Smet, D., Saeger, S. and Zhang, S. (2011). T-2 toxin, a trichothecene mycotoxin: Review of toxicity, metabolism, and analytical methods. Journal of Agricultural Food Chemistry; 59, 34413453.

Marijani, E., Kigadye, E. and Okoth, S. (2019). Occurrence of Fungi and Mycotoxins in Fish Feeds and Their Impact on Fish Health. International Journal of Microbiology; 1, 1-17.

Martins, H.M., Guerra, M.M. and Bernardo, F.M. (2007). Occurrence of aflatoxin B1 in dairy cow's feed over 10 years in Portugal (19952004). Review. Iberoam Micol; 24, 69-71

Moura, M.A., Machado, C.H., Porfirio, L.C. and Freire, R.B. (2004). Effects of ochratoxin A on broiler leukocytes. Revista Brasileira de Ciência Avícola; 3,187- 190.

Okoli, I.C., Nweke, C.U., Okoli, C.G. and Opara, M.N. (2006 a). Assessment of the mycoflora of commercial poultry feeds sold in the humid tropical environment of Imo State, Nigeria. International Journal of Environmental Science and Technology; 1, 9-14.

Okoli, I.C., Endujihe G.E. and Ogbuewu, I.P. (2006 b). Frequency of isolation of Salmonella from commercial poultry feeds and their antimicrobial resistance profiles, Imo State, Nigeria. Online Journal of Health Allied Science; 5, 2-3.

Okoli, I.C., Omede, A.A., Ogbuewu, I.P., Ekwuagana I.C. and Ndujihe, G.E. (2007 a). Frequency of mycotoxin feom commercial poultry feeds and feed raw materials in humid tropical environment of Imo State, Nigeria. Proceeding of $12^{\text {th }}$ Annual Conference of Animal Science Association of Nigeria. September 10-13, Osun State, Nigeria; 115.

Okoli, I.C., Ogbuewu, I.P., Okorie, J.O., Okoli, G.C., Ucheghu, M.C., Opera, M.N. and Ibekwe, I.V. (2007 b). Assessment of microflora of poultry feed raw materials in the humid tropical environment. Journal of Animal Science; 3, 59.

Omede, A.A. (2008). Critical issues in poultry feed quality evaluation in Nigeria Proceedings of the $23^{\text {rd }}$ World Poultry Congress, June 29July4, Brisbane, Australia; 455.

Patterson, D.S. and Roberts, B.A. (1980). Aflatoxin B1 in dairy concentrates and other animal feedstuffs. Veterinary Record; 107, 249-252.

Ratcliff J. 2002. The role of mycotoxins in food and feed Safety. Presented at AFMA (Animal Feed Manufacturers Association) meeting on 16 August, 2002. Available 
from: http://www.facs.org.uk. Accessed Jun 2008.

Rodrigues, I., Handl, J. and Binder, E.M. (2011). Mycotoxin occurrence in commodities, feeds and feed ingredients sourced in the Middle East and Africa. Food Additives and Contaminants Part B; 3, 168-179.

Rosa, C., Cavaglieri, L., Ribeiro, J., Keller, K., Alonso, V. and Chiacchiera, S. ( 2008). Mycobiota and naturally-occurring ochratoxin A in dairy cattle feed from Rio de Janeiro State, Brazil. World Mycotoxin Journal; 2, 195-201.

Sharma, R.P. (1993). Immunotoxicty of mycotoxins. Journal of Dairy Science; 76, 892-987.

Sonal, S. and Oruc, H.H. (2000).Natural mycotoxin levels in mixed feed taken from poultry farm in Bursa Province.Van Veterinary Journal; 2, 1-6.

Souza, M.L., Sulyok, M., Silva, O.F., Costa, S.S., Brabet, C., Junior, M.M., Sekiyama, B.L., Vargas, E.A., Krska, R. and Schuhmacher, R. (2013). Occurrence of mycotoxins in maize and poultry feeds from Brazil by liquid chromatography/ tandem mass spectrometry. Science World Journal; 1-9.
SPSS. (2011). Statistical packages for the social sciences. 20th edition Chicago: IBM Inc.

Sultana, N. and Hanif, Q. (2009). Mycotoxin contamination in cattle feed and feed ingredients. Pakistan Veterinarian Journal; 4, 211-213.

Vega, M., Munoz, K., Sepulveda, C., Aranda, M., Campos, V. and Villegas, R. (2009). Solidphase extraction and HPLC determination of Ochratoxin A in cereals products on Chilean market. Food Control; 631-634.

Wayne, L.B. (2007). Mycotoxins in the food chain: human health implications. Asia Pacific Journal of Clinical Nutrition; 16, 95-101.

Wyatt, R.D., Hamilton, P.B. and Burmeist. H.R. (1973). Effects of T-2 Toxin in Broiler Chickens. Poultry Science; 52, 1853-1859.

Wyatt, R.D., Hamilton, P.B. and Burmeister, H.R. (1975). Altered feathering of chicks caused by T-2 toxin. Poultry Science; 54, 1042-1045.

Y1ldı, G. (2009). Determination of the contamination of the ochratoxine $\mathrm{A}$ in feeds and feedstuffs into the different animal enterprise in Turkey. Veterinary Journal of Ankara University; 56, 131-135.

ييسبونا ئالفيّن كيانهوهرا و كهرهستيّن دهستيّيكى بو جيّكرنا ئالفى ب جهند جوريّن زههريّن كيفكويى

يوخته

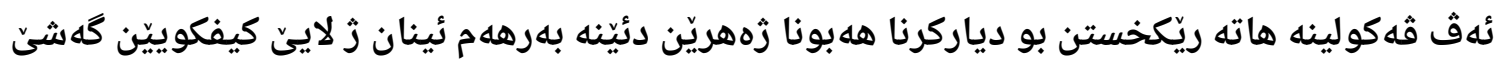

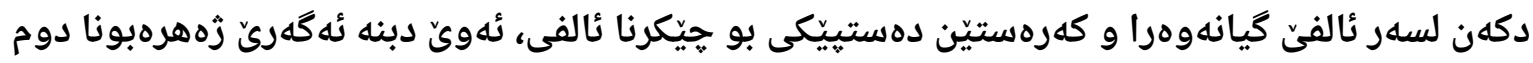

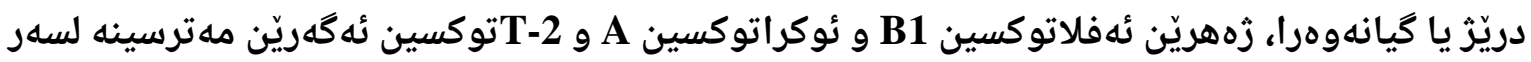

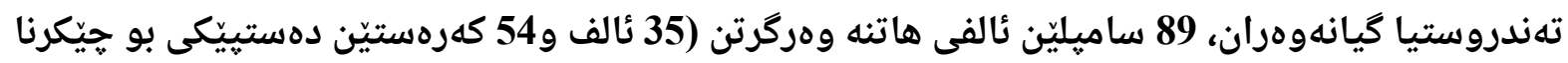

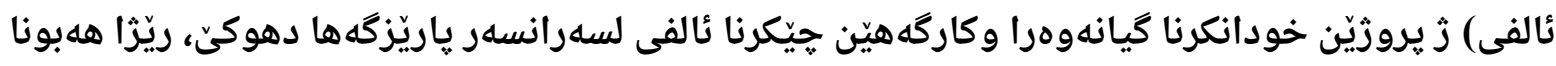

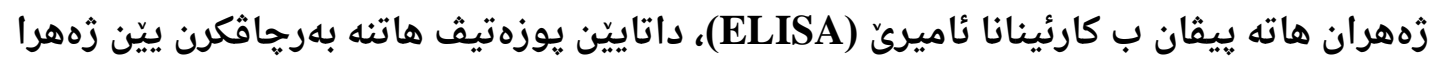
ئه فلاتوكسين B1 يوزهتيف دهرجووين 7 ساميل بون ب ريّزا

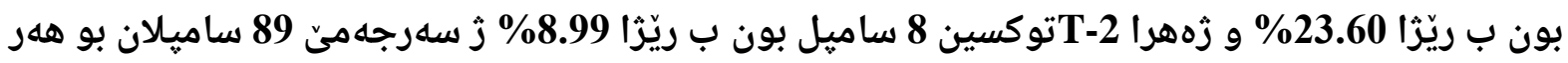

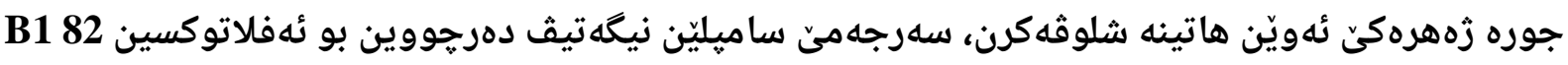

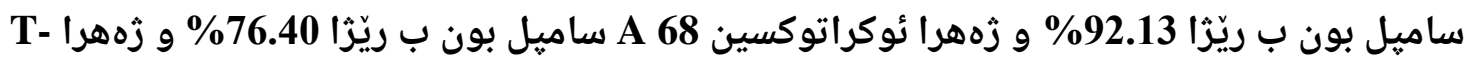

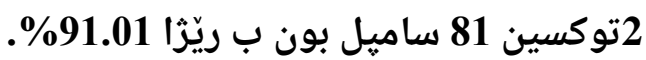

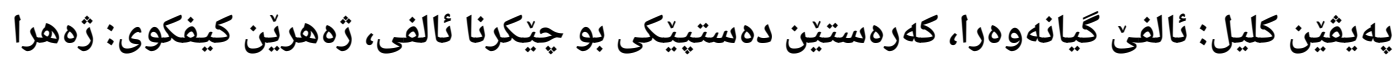

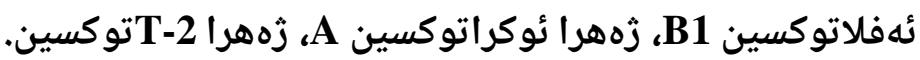


تلوث بعض السموم الفطرية في علف الحيوانات ومكونات الاولية لتكوين العلائق

الخلاصة

تنتج الفطريات أنواعًا مختلفة من السموم الفطرية في ظل ظروف التخزين غير مناسبة وأثناء فترة

زراعة المحاصيل التي تسبب سمية مزمنة أو حادة للحيوانات. الأفلاتوكسين B1 والاكراتوكسين A و

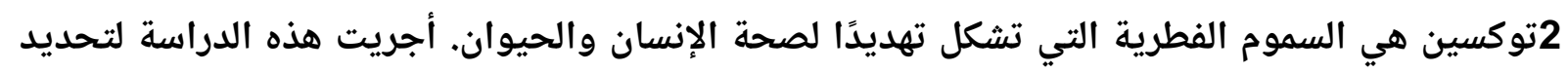

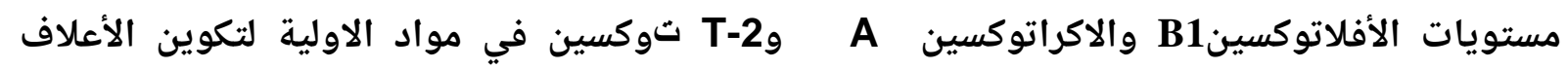
والأعلاف الجاهزة في مصانع التكوين لأعلاف الحيوانات ومشاريع الثروة الحيوانية في محافظة دهوك. تم جمع العينات المستخدمة للتحليل (35 علف مخلوط و 54 مادة اولية للأعلاف) من مصانع ومشاريع

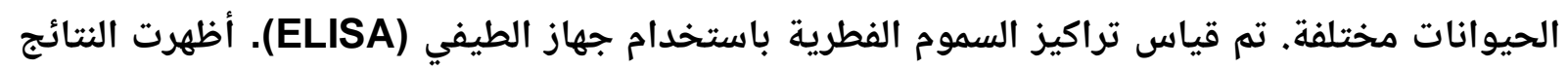

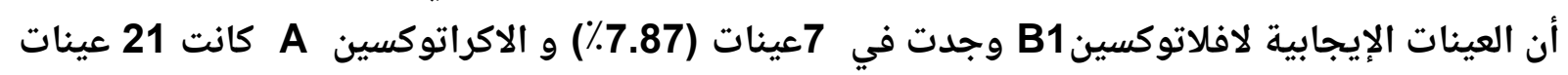

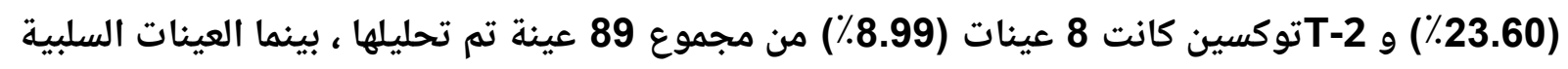
منها لافلاتوكسين

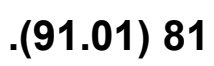

الكلمات الدالة: علف الحيوانات، مواد الاولية لتكوين الأعلاف، السموم الفطرية: الأفلاتوكسينB1، اكراتوكسين A، توكسين T-2. 